\title{
HUBUNGAN ANTARA KEMATANGAN BERAGAMA DENGAN KOMPETENSI INTERPERSONAL MAHASISWA
}

\author{
Fuad Nashori \\ Universitas Isiam indonesia \\ Sugiyanto \\ Univer sitas Gadjah Mada
}

\section{Abstract}

This researoh aimed to examine the relationship botween the marure religious sentiment and the interpersonal competence. The hypothesis was tested there was a positive corrolation betwen mature religious sentiment and the interpersonal competence.

The subject of the research were psychology students in Yogyakarta (100 students from islamic University of indonesia, 101 students from Gadjah Mada University, and ror students from Wangsa Manggala University). Two instruments were administered to gather the data the interpersonal competence scale and the mature religious sentiment scate.

The Product Moment Correlation technique was applied to analyze the data. The result indicated that there was a positive and significant correlation between mature religious sentiment and the interpersonal competence.

Key Words : the interpersonal competence, the mature religious sentiment, the university students.

Fuad Nashori adalah peneliti di Lembaga Penelitian Ull dan dosen Fakultas Psikologi Uil. Menyelesaikan pendidikan psikologi S1 dan S-2 di Fakultas Psikologi UGM. Sebagian besarwaktu senggangnya digunakan untuk membaca, meneliti, menulis, dan berorganisasi. Minat utamanya adaiah psikologi islami, psikologi agama, psikologi sosial, dan psikologi perkembangan.

Suglyanto adalah dosen pasca sarjana Fakultas Psikologi UGM. Menyelesaikan pendidikan psikologi S-1 of UGM, S-2 dan S-3 of South Carolina, USA. Meminati psikologi teknologi, psikologi eksperimen. psikologi sosial, dan motodologi penelitian.

\section{PENDAHULUAN}

T/ esadaran akan pentingnya kemam1. puan menjalin komunikasi dengan orang lain belakangan ini semakin meningkat, baik di katangan ahli psikologi maupun di kalangan masyarakat umum. Dipercayai bahwa salah satu kunci keberhasilan hidup manusia adalah kemampuannya melakukan dan membina hubungan antar pribadi dengan orang lain. Berbagai kisah nyata menunjukkan bahwa keberhasilan-keberhasilan dalam pekerjaa n dan dalam berbagai bidang kehidupan lainnya dipengaruhi oleh kemampuan mengeloia hubungan antar pribadi dengan orang iain. 
Salah satu kualitas hidup seseorang yang banyak menentukan keberhasilan menjalin komunikasi dengan orang lain adalah kompetensi interpersonal. Kompetensi interpersonal sendiri, menurut Spitzberg dan Cupach (dalam DeVito, 1996). dapat diartikan sebagai suatu kemampuan melakukan hubungan interpersonal secara efektif. Kemampuan ini ditandai oleh adanya karakteristik-karakteristik psikoiogis tertentu yang sangat mendukung dalam menciptakan dan membina hubungan antar pribadi yang baik dan memuaskan. Oleh Buhrmester, Furman, Wittenberg, dan Reis (1988) dikatakan bahwa kompetensi interpersonal meliputi kemampuan berinisiatif membina hubungan interpersonal, kemampuan membuka diri, kemampuan bersikap asertif, kemampuan untuk memberikan dukungan emosional dan kemampuan untuk mengelola dan mengatasi konflik-konflik yang timbul dalam hubungan interpersonal.

Disinyalir bahwa kompetensi interpersonal di kalangan masyarakat holonesia saat ini pada umumnya dan mahasiswa pada khususnya dalam kondisi yang memprinatinkan. Hal ini ditandai oleh semakin menurunnya kesediaan menyapa dan memperkenalkan diri kepada orang lain. kecenderungan untuk mengungkapkan perasaan secara agresif dan bukan asertif, adanya kecenderungan menyakahkan orang lain bila terdapat konflik, meningkatnya upaya penyelesaian konflik dengan kekerasan, dan seterusnya.

Salah satu momen yang banyak peneliti amati adalah kejadian saat orang-orang menumpang kereta api. Saat ada di dalam gerbong yang kursinya ditata saling berhadap-hadapan, terthat penumpang duduk. lalu membaca koran, makan nasi atau makanan lainnya, dan sangat jarang yang berinisiatif berkenalan dengan teman seperjalanannya.
Tidak kurang dari itu, pada saat ini tampak orang-orang semakin sulit untuk mendengarkan pembicaraan orang lain. Orang-orang lebih suka berbicara, bila perlu dengan suara yang sekeras-kerasnya dan sepedas-pedasnya, den tidak suka mendengarkan pembicaraan orang lain. Ada sebuah sindiran untuk menggambarkan keadaan ini: Orang Indonesia saat in tidak memerlukan lombok atau cabe, karena mulutnya sudah pedas. Kadang ditemukan juga orang-orang yang begitu mudah merespon stimulus yang berupa saran. masukan, kritik yang sampai padanya secara reaktif-emosional. Bila terlibat konflik, orang begitu mudah berbuat kasar dan kejam terhadap orang lain. Orang mudah tersulut berbuat sesuatu yang destruktif. Bila ada konflik, mereka tidak berusaha segera menyelesaikannya, tapi malah justru melanjutkan ke pertengkaran atau usaha saling menjałuhkan.

Problem kompetensi interpersonal ini juga terjadi pada mahasiswa. Berbagai peristiwa belakangan menunjukkan bahwa kompetensi mahasiswa layak mendapatkan sorotan. Beberapa contohnya adalah pemukulan yang dilakukan oleh mahasiswa terhadap kawannya, menyampaikan pan dangan kepada dosen dengan cara menyerang ketidaksediaan untuk mendengarkan pikiran atau perasaan dari orang yang sedang terlibat konflik dengannya.

Berdasarkan Laporan Birnbingan dan Konseling Mahasiswa UGM (Partosuwido. 1993) diketahui ternyata begitu banyak persoalan pribadi dan sosial-interpersonal pada diri mahasiswa. Masalah-masalah sosial-interpersonal meliputi kesulitan hubungan dengan sesama maupun lawan jenis, kurang mampu mengendalikan emosi. sering terlibat kontlik dengan teman. Mereka juga mengelunkan persoalan pribadi yang pada gilirannya dapat menyulitkan mereka dalam melakukan hubungan interpersonal, 
seperti rendah dirl, sikap tertutup. kecemasan tinggi, tidak mampu mengendalikan diri, dan mudah mendapat pengaruh orang lain.

Mencermati keadaan di atas muncul pertanyaan, apa yang menjadikan kompe. tensi interpersonal ada, bertumbuh dan berkembang dalam diri seseorang pada umumnya dan mahasiswa pada khususnya?

\section{DASAR TEDRI}

Berbagai penelitian menunjukkan bahwa kompetensi interpersonal mahasiswa, subjek penelitian ini, dipengaruhi oleh lingkungan keluarga maupun proses hidup yang dijalani seseorang dengan masyarakatnya. Kebiasaan untuk hidup bersama darı mengembangkan pergaulan yang intens menjadikan kompetensi interpersonal seseorang lumbuh dan berkembang. Diungkapkan Danardono (1997) bahwa mahasiswa yang aktif dalam kegiatan kepecintaalaman memiliki perbedaan yang signifikan dengan mahasiswa yang tidak aktif dalam kepecintaalaman, khususnya dalam hal kompetensi interpersonal. Mahasiswa yang aktif dalam kegiatan kepecintaalaman memiliki kompetensi interpersonal yang lebih tinggi dibanding mahasiswa bukan pecinta alam. Penelitian yang lain yang membandingkan antara mahasiswa yang aktit dan mahasiswa yang tidak aktif dalam organisasi, yang dilakukan Widiastuti dan Anggraini (1998) menunjukkan hasil yang berbeda dengan hasil penelitian Danardono. Penelitian yang terakhir ini menunjukkan bahwa tidak ada perbedaan kompetensi interpersonal antara manasıswa yang aktif dalam organisasi dan tidak aktif dalam organisasi.

Ada pula peneliti yang menduga bahwa latar belakang program studi juga mem- pengaruhi kemampuan berkomunikasi interpersonal mahasiswa. Hasil penelitian yang dilakukan Widuri (1995) ternyata menunjukkan bahwa mahasiswa ilmu-ilmu sosial, yang diwakili manasiswa Fakultas ilmu Sosial dan IImu Politik UGM, dan mahasiswa ilmu-ilmu eksakta, yang diwakili mahasiswa Fakultas Teknik UGM, ternyata memiliki kemampuan yang seimbang dalam hal berkomunikasi interpersonal. Hat ini menunjukkan bahwa interaksi yang cukup intens menjadikan kemampuan berkomunikasi secara interpersonal dapat tumbuh dan berkembang.

Faktor-faktor lainnya yang dinilai memiliki peranan terhadap kompetensi interpersonal adalah faktor-faktor internal individu, di antaranya adalah kemafangan beragama (Wulfi, 1991).

Kematangan beragama yang ada dalam diri seseorang juga mempengaruhi kompetensi interpersonalnya. Semua agama mendorong individu untuk selalu menghadirkan kebaikan dan kasih sayang di antara sesama manusia (Smith, 1991). Agar upaya berbuat baik terhadap orang lain dapat dirain secara optimal orang perlu membangun komunikasi dengan orang lain. Agama menganjurkan agar individu berinisia tif menyapa dan mengucapkan salam, menghidupkan persahabatan di antara sesama, segera mengatasi konflik yang terjadi di antara manusia, memberi dukungan sosial dan dukungan emosional kepada orang lain terutama yang menghadapi kesulitan hidup. dan seterusnya (Maruzi, 1995).

Bila individu dapat mengetahui dan menghayati ajaran agama secara mendafam, serta memiliki konsistensi mora! terhadapnya, maka mereka memiliki sebagian dari ciri-ciriorang yang matang dalam beragama. Orang yang memiliki kematangan beragama dinilai memiliki modal untuk memiliki kompetensi interpersonal. 


\section{HIPOTESIS}

Dari uraian sebagaimana disebutkan d atas, dapat dirumuskan hipotesis penelitian sebagai berikut: Ada hubungan kematangan beragama dengan kompelensi interpersonal pada mahasiswa.

\section{METODE}

Penelitian ini menggunakan variabel tergantung kompetensi interpersonal, variabel bebas tiga macam, yaitu kematangan beragama.

\section{Subjek Penelitian}

Subjek adalah mahasiswa Fakultas Psikologi d Yogyakarta, baik mahasiswa Perguruan Tinggi Negeri (PTN) dan Perguruan Tinggi Swasta ( $\mathrm{P}^{\top} \mathrm{S}$ ), berienis kelamin laki-laki dan perempuan, serta mahasiswa junior dan senior. Pengambilan subjek dilakukan dengan melode purposive sampling.

Langkan pertama yang dilakukan adalah mendata Fakultas Psikologi di Yogyakarta yang ternyata terdiri atas Fakultas Psikologi UGM (PTN), UII. UNWAMA, UP '45, USD, UAD, dan Sarjanawiyata Taman Siswa (PTS).

Langkah kedua dilakukan dengan menentukan perguruan tinggi negeri dan swasta yang terdiri atas PTS umum dan PTS agama. Yang akhirnya menjadi subjek adalah mahasiswa-mahasiswa Fakultas Psikologi UGM, UII, dan UNWAMA Yogyakarta.

Langkah ketiga adalah memilih subjek berdasarkan seniorilas. Mahasiswa dikelompokkan menjadi đưa, yaitu mahasiswa senior dan mahasiswa junior. Mahasiswa senior terdiri atas mahasiswa angkatan 1995 hingga 1997. Mahasiswa junior terdiri atas mahasiswa angkatan 1998 hingga 1999. Mahasiswa senior berịumlah 144 orang dan junior 158 orang.
Langkah keempat adalah memilin subjek dengan melibalkan dua jenis kelamin sekaligus. Pari segi jenis kelamin, mereka terbagi atas dua kelompok, yaitu jenis kelamin laki-laki maupun perempuan. Subjek laki-laki sebanyak 99 orang sementara perempuan berjumlah 203 orang.

Subjek di atas memperoleh kesempatan yang sama untuk menjadi sampel. Jumlah mahasiswa yang menjadi subjek adalah 302 orang.

\section{Alat Ukur untuk Pengambilan Data}

Untuk mengetahui keadaan subjek, khususnya mengenai konsep diri, kematangan beragama dan kompetensi interpersonal. digunakan alat ukur yang bernama skala kompetensi interpersonal (SKI) dan skala kematangan beragama (SKB). Dua alat ukur di atas mengikut model Skaia Likert. Subjek memiliki kesempatan memilih jawaban dengan menggunakan salah satu pilinan, yaitu sangat sesuai, sesuai, netral, tidak sesuai, dan sangat tidak sesuai.

SKI mengukur aspek-aspek kemampuan mengambit inisiatif berkenalan, kemampuan membuka diri, Kemampuan memberi dukungan emosional, Kemarnpuan bersikap asertif, dan kemampuan menyelesaikan konflik. Uji kesahihan skala kompetensi interpersonal menghasilkan koefisien aitem-total yang sahih bergerak antara 0,258 sampai 0,568 . Koefisien alpha menunjukkan 0,928 . Di antara 35 butir yang sahit. hanya terdapat 30 butir yang digunakan dalam penelitian ini.

SKB mengungkap aspek-aspek kemampuan diferensiasi, komprehensif integral, konsistensi moral, heuristik, dan karakter dinamis. Uji kesahihan skala kematangan beragama menghasilkan koefisien aitem-total yang sahih bergerak antara 0,270 Sampai 0,671 . Adapan koefiisien alpha skala ini adalah 0,943 . Di antara 47 buir 
yang sahih, terdapat 30 butir yang digunakan dalam penelitian ini.

\section{HASIL PENELITIAN} berikut:

Penelitian menunjukkan hasil sebagai

a Penggolongan data yang dilakukan terhadap subjek penelitian menurut jenis kelamin. Seluruh subjek penelitian berjumlah 302 orang. Subjek yang berjenis kelamin laki-laki berjumlah 99 orang, sedangkan subjek perempuan sebanyak 203 orang. Sesuai dengan perbandingan pria dan wanita mahasiswa psikologi umurnnya, yaitu satu banding dua, maka komposisi subjek of atas dapat dikatakan relatif seimbang.

a. Penggolongan data yang dilakukan terhadap subjek penelitian menurut universitas. Keseluruhan subjek adalah 302 orang. Mereka terdiri atas 100 mahasiswa Fakultas Psikologi UII. 101 dari Fakultas Psikologi UGM, dan 101 dari Fakultas Psikologi UNWAMA. Berdasarkan data d atas, dapa: disimpulkan komposisi ketiga asal subjek dalam keadaan relatil seimbang. b. Penggolongan data yang dilakukan temadap subjek penelitian berdasarkan senioritas. Keseluruhan subjek adalah 302 orang. Berdasarkan angkatan mereka dibedakan menjadi mahasiswa senior, yang ter diri atas mahasiswa angkatan 1995 hingga 1997 dan mahasiswa junior yang terdiri dari angkatan 1998 hingga 1999. Mahasiswa senior berjumlah 144 dan mahasiswa junior 158 orang. Berdasarkan komposisi di atas, dapat diketahui bahwa perbandingan mahasiswa senior dan junior relatif seimbang.

c. Kategori kompetensi interpersonai. Pengelompokan subjek dilakukan dalam iga kategori kompetensi interpersonal, yaitu kelompok tinggi, sedang, dan rendah. Dengan perhitungan Azwar (1993), diketahui subjek penelitian ini berada padatingkat kompetensi interpersonal sedang $(81,5 \%)$ dan tinggi $(18,5 \%)$. Perhitungan ini dilakukan dengan melibatkan rerata teoritik dan deviasi standar teoritik dari skala kompetensi interpersonal. Rerata teoritik untuk data ini adalah 90 dengan deviasi standar sebesar 20. Dengan demikian. pengelompokan tersebut secara lengkap adalah sebagai berikut:

Tabel I

Kategori Kompetensi Interpersonai $(\mathbf{N}=302)$

\begin{tabular}{|l|l|l|l|}
\hline Kategori & Rentang Sektor & Jumlah & Persentase \\
\hline Tinggi & $121-150$ & 56 & $18,5 \%$ \\
Sedang & $61-120$ & 246 & $81,5 \%$ \\
Rendah & $31-60$ & 0 & $0 \%$ \\
\hline
\end{tabular}


a. Kategori kematangan beragama. Pengelompokan subjek dilakukan dalam tiga kategori kematangan beragama, yaitu kelompok tinggi, sedang, dan rendah. Dengan menggunakan perhitungan Azwar (1993), dapat diketahui bahwa subjek penelitian ini berada pada tingkat kematangan beragama sedang $(52,9 \%)$ dan tinggi $(47,1 \%)$.
Perhitungan ini dilakukan dengan melibatkan rerata teoritik dan deviasi standar teoritik dari skala kematangan beragama. Rerata teoritik untuk data ini adalah 90 dengan deviasi standar sebesar 20. Dengan demikian, pengelompokan tersebut secara lengkap adalah sebagai berikut:

Tabel \#

Kategori Kematangan Beragama $(\mathbf{N}=\mathbf{3 0 2})$

\begin{tabular}{|l|c|c|c|}
\hline \multicolumn{1}{|c|}{ Kategori } & Rentang Sektor & Jumlah & Persentase \\
\hline Tinggi & $121-150$ & 142 & $47,1 \%$ \\
Sedang & $61-120$ & 160 & $52.9 \%$ \\
Rendah & $31-60$ & 0 & $0 \%$ \\
\hline
\end{tabular}

e. Hasil Analisis data. Setelah dilakukan analisis product moment, penelitian menghasilkan temuan-temuan sebagai berikut: hasil analisis data mengenai hubungan antara kematangan beragama dan kompetensi interpersonal menunjukkan koefisien korelasi $r=$ 0,2058 dengan $p<0,001$. Hal ini menunjukkan ada korelasi yang signifikan antara kematangan beragama dan kompetensi interpersonal pada mahasiswa.

\section{PEMBAHASAN}

Hasil penelitian menuniukkan bahwa ada hubungan yang signifikan antara kematangan beragama dengan kompetensi interpersonal pada mahasiswa. Kematangan beragama dapat dijadikan prediktor untuk mengetahui adanya kompetensi interpersonal. Korelasi yang positif ini menuniukkan bahwa kenaikan tingkat kematangan beragama secara proporsional akan dikuti oleh kenaikan tingkat kompetensi interpersonal.

Dinamika psikologis tentang korelasi kematangan beragama dengan kompetensi interpersonal dapat dijelaskan sebagai berikut. Orang yang memiliki kematangan beragama mengarahkan dirinya kepada orang lain, dikarenakan setiap agama membawakan misi untuk menghadirkan kebaikan dan kesejahteraan bagi hidup bersama. Dengan kesadaran moral semacam ini, mereka mengembangkan kompetensi interpersonalnya.

Orang-orang yang memiliki kepribadian sehat dan matang mengarahkan dirinya kepada orang lain. Mereka aktif terlibat dan 
terikat pada sesuatu atau seseorang yang ada di luar dirinya. Orang yang matang bukanlah penonton kehidupan yang pasif, terisolasi dan menarik diri dari orang lain, tetapi dia benar-benar "menyatu" atau terlibat sepenuhnya dalam kehidupan bersama orang lain. Mereka mempunyai kemampuan mencintai dan memperluas dirinya ke dalam hubungan yang penuh perhatian dengan orang-orang lain

Sementara di sisi lain diketahui bahwa setiap agama menempatkan pemberian kebaikan dan kasih sayang kepada orang tain sebagai tuntunan yang utama (Smith, 1991). Dalam Islam dikenal konsep "rahmatan lil "alamin". Dalam Kristen terdapat konsep "kasih".

Adanya dorongan dari dalam untuk mengarahkan diri kepada orang lain dan adanya tuntutan untuk berbuat sesuatu yang baik pada orang lain menjadikan seseorang mengembangkan kompetensi interpersonal. Keadaan di atas dapa: digambarkan sebagai pertemuan yang sinergis. Kecenderungan mengembangkan kompetensi interpersonal ini akan lebih efektif, terutama pada seseorang yang kuat konsistensi moralnya. Orang yang memiliki konsistensi moral akan berbuat secara lurus dengan :untunan-tuntunan moral yang dikutinya. Sebagai orang yang konsisten secara moral dengan ajaran agamanya, maka prinsip-prinsip kebaikan dan kebenaran yang diajarkan agamanya yang berkaitan dengan masalah perhatian orang lain akan diupa-yakan untuk dilakukan. Karena ajaran agama selafu menuntun bahwa setiap kali bertemu orang harus menyapa dengan salam, maka ia akan menyapa setiap orang yang sudah dikenal dan mengajak berkenalan orang-orang yang belum dikenal. Bila mereka ada di suatu perjalanan kereta api, maka mereka akan mengembangkan inisiatif berkenalan, membuka diri, dan mengembangkan persahabatan, inklan yang menjadkan seorang mahasiswa dengan inisiatif mendekati, bersahabat, dan berkiprah bersama orang. orang yang ada di sekitarnya.

Selanjutnya, berkaitan dengan kematangan beragama dan kemampuan menangani konflik, dapat dikatakan orang yang memiliki kematangan beragama akan berusaha mengelofa dan menyelesaikan konflik dengan sebaik-baiknya. Disebutkan oleh Ailport (dalam Schultz, 1998) bahwa kepribadian yang matang sabar terhadap tingkah laku orang-orang lain dan tidak mengadili atau menghukumnya. Orang matang atau dewasa ini bila memiliki kemampuan diferensiasi, yang menjadikannya paham akan ajaran agamanya, akan menyelesaikan konflik yang merugikan semua pihak. Oieh karena itu, bita terjadi kontlik mereka tidak menghukumnya, tapi akan menyelesaikannya. Kesaiahan harus diakhiri dengan saling pengertian dan saling memaafkan. la akan menyelesaikan konflik dengan kawan atau saudaranya.

\section{SIMPULAN}

Dari penelitian ini dapat diambil simpulan bahwa kematangan beragama memiliki hubungan dengan kompetensi interpersonal mahasiswa. Mahasiswa yang memiliki kompetensi interpersonal tinggi ternyata juga memiliki kematangan beragama dan konsep diri yang tinggi. Kematangan beragama dapat dijadikan prediktor kompetensi interpersonal mahasiswa. 


\section{DAFTAR PUSTAKA}

Azwar, S. 1993. Kelompok Ini Memiliki Harga Diri yang Rendah, "Kok Tahu?" Buletin Psikologi, I (2), 13-17.

Azwar, S. 1997. Aeliabilitas dan Validitas. Yogyakarta: Pustaka Pelajar.

Azwar, S. (1999). Penyusunan Skala Psikologi. Yogyakarta: Pustaka Pelajar.

Bierman, I. K., Miller, L C., \& Stabb, D. S 1987. Improving the Social Behavior and Peer Acceptance of Rejected Boys: Effect of Social Skills Training with Instructions and Prohibitions. Journal of Consulting and Clinical Psychology. 55, 2. $194-200$.

Buhrmester, D., Furman. W., Wittenberg M. T. \& Reis. D. 1988. "Five Domains of Interpersonal Competence in Peer Relationships." Journal of Personality and Social Psychology, 55 (6), 991 1008.

Danardono, W. 1997. Kompetensi interpersonal Mahasiswa Ditinjau dari Keikutsentaan pada Kegiatan Pecinta Alam. Laporan Penefitian (tidak Diterbitkan). Yogyakarta: Fakultas Psikologi UGM.

Devito, J. A 1996. The interpersonal Communication Book. 7th edition. New York: Harper Collins College Publishers.

Goleman, D. 1995. Emotional Inteligence. New York: Bantam.

Hadi, C. 1994. Suatu Penelitian Eksperimental Mengenai Efek Pola Komunikasi, Bentuk Pemecahan Masalah, dan Jenis Kelamin terhadap Efisiensi Pemecahan Masalah. Tesis (Vidakofiterbitkan). Yogyakarta: Program Pasca sarajana UGM.
Maruzi, M. 1995. Koleksi Hadis Sikap dan Pribadi Mustim. Jakarta: Pustaka Amani.

Partosuwido, S. F. 1993. Penyesuaian Diri Mahasiswa dalam Kaitannya dengan Konsep Diri, Pusat Kendali dan Status Perguruan Tinggi. Jurnal Psikologi, $\mathrm{XX}$ 1, 32-47.

Rakhmat, J. 2000. Psikologi Komunikasi. Cetakan Ketiga belas. Bandung: Penerbit PT Remaja Rosdakarya.

Santoso, S. 2000. SPSS: Mengolah Data Statistik Secara Profesional. Cetakan Kedua. Jakarta: PT Elex Media Computindo.

Schultz. D. 1998. Psikologi Pertumbuhan: Model-model Kepribadian Sehat. Cetakan Keenam. Tejemahan: Yustinus. Yogyakanta: Penerbit Kanisius.

Siławati, R.D.E. 1991 . Perbedaan Motivasi Berokahraga antara Pria dan Wanita pada Anggota Fitness Centre di Kotamadya Yogyakanta. Skripsi (tidak diterbitkan). Yogyakarta: Fakultas Psikologi UGM.

Smith, H. 1991. Agama-agama Manusia. Cetakan Kedua. Terjemahan: Saafruddin Bahar. Jakarta: Yayasan Obor Indonesia.

Tim Penyusun Kamus Pusat Pembinaan dan Pengembangan Bahasa. (1989). Kamus Besar Bahasa Indonesia. Cetakan Kedua. Jakara: Depdikbud \& Balai Pustaka.

Widiastuti, A \& Anggraini, Z 1998. Perbedaan Kompetensi Interpersonal antara Mahasiswa Aktivis dan Mahasiswa Bukan Aktivis. Laporan Penelitian (tidak dipublikasikan). Yogyakarta: Universitas Islam Indonesia. 
Widuri, N. F. 1995. Komunikasi Interpersonal pada Mahasiswa Fakultas Teknik dan Mahasiswa Fisipol. Skripsi (tidak diterbitkari). Yogyakarta: Fakultas Psikologi UGM.

Wrigtsmarı, L S. \& Deaux, K. 1981. Social Psychology in 80's. 3rd edition.
Monterey: Brooks/Cole Publisihing Company.

Wultt, D.M. 1991. Psychology of Rerigion: Classic and Contemporary Views. New York: John Witey and Sons. 